\title{
The prevalence of subclinical hypothyroidism in obese children and adolescents and its effects on metabolic parameters
}

\section{Obez çocuk ve adolesanlardla subklinik hipotiroidi sıklığı ve metabolik parametreler üzerine olan etkileri}

Nurullah Çelik

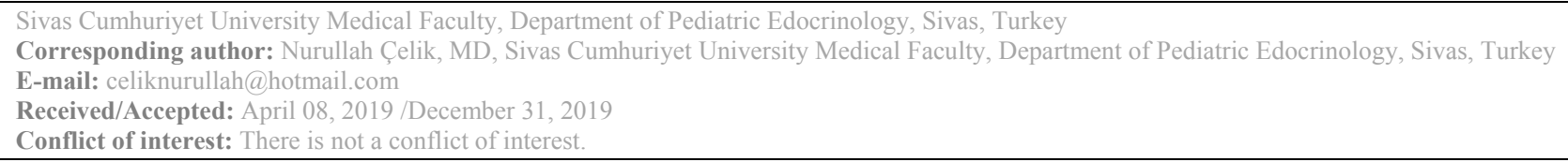

\section{SUMMARY}

Objective: To compare cardiovascular risk factors in obese patients with or without Subclinical Hypothyroidism (SH), also to estimate the prevalence of $\mathrm{SH}$ in obese children and adolescents.

Method: A total of 226 obese children and adolescents aged 6-18 years were included in the study. Two groups were created as euthyroid group $(\mathrm{n}=195)$ and $\mathrm{SH}$ group $(\mathrm{n}=31)$. After an 8-12 hour overnight fasting, serum blood glucose, insulin, HDL, LDL, cholesterol, triglyceride TSH, free T4, ALT, AST levels were measured. HOMA-IR and atherogenic index (AI) were calculated.

Results: Prevalence of SH was estimated as $14.1 \%$. The values of fasting glucose, fasting insülin, ALT, AST, TSH, HOMA-IR levels were significantly higher in SH group than euthyroid group. There was a positive correlation between TSH and fasting glucose, insülin, triglyceride, ALT, AST, HOMA-IR, AI. It was also demonstrated that the TSH level was significantly and independently related to HOMA-IR value in multiple regression analysis $(\mathrm{p}=0.001)$.

Conclusions: Obese patients with SH may be more susceptible to metabolic complications than euthyroid subjects.

Keywords: Adolescent, child, obesity, prevalence, subclinical hypothyroidism
(D) Nurullah Çelik

ORCID IDs of the authors: N.Ç. 0000-0003-1583-6807

\section{ÖZET}

Amaç: Subklinik Hipotiroidi(SH)'si olan ve olmayan obezlerde kardiyovasküler risk faktörlerini karşılaştırmak ve obez çocuk ve adolesanlarda SH sıklığını hesaplamak

Yöntem: Çalışmaya yaşları 6-18 arası değişen 226 obez çocuk ve adolesan alındı. Ötiroid grup (n=195) ve SH grup ( $\mathrm{n}=31$ ) olmak üzere 2 grup oluşturuldu. 8-12 saatlik açlığı takiben, kan şekeri, insülin, HDL, LDL, kolesterol, trigliserit, TSH, serbest T4, ALT, AST düzeyleri ölçüldü. HOMA-IR ve Aterojenik İndeks (AI) hesaplandi.

Bulgular: Subklinik Hipotiroidi sıklığı \%14,1 olarak hesaplandı. Açlık kan şekeri, insülin ALT, AST, TSH ve HOMAIR düzeyleri SH grupta ötiroid grupla karşılaştırıldığında istatistiksel olarak anlamlı düzeyde daha yüksekti. TSH düzeyi ile açlık kan şekeri, insülin, trigliserit ALT, AST, HOMA-IR ve AI arasında pozitif bir korelasyon vardı. Ayrıca multipl regresyon analizi yapıldığında TSH düzeyinin HOMA-IR ile anlamlı düzeyde ilişkili olduğu görüldü ( $p=0.001)$.

Sonuç: Subklinik hipotiroidisi olan obez çocuk ve adolesanlar ötiroid grupla karşılaştırıldığında metabolic komplikasyonlara daha yatkındır.

Anahtar sözcükler: Adolesan, çocuk, obezite, prevalans, subklinik hipotiroidi 


\section{INTRODUCTION}

Subclinical hypothyroidism ( $\mathrm{SH}$ ) is defined as elevated serum thyroid stimulating hormone (TSH) in the presence of normal serum total and free thyroxine (fT4) levels ${ }^{1}$. The prevalence of SH is $4-20 \%$ in adults, and $1.5-3 \%$ in children ${ }^{2}$. There are several factors associated with $\mathrm{SH}$ such as Hashimoto's thyroiditis, iodine deficiency, medications, gene defects, genetic syndromes, and obesity, etc.

It is well documented that overt hypothyroidism related metabolic abnormalities such as coroner artery disease, insülin resistance and dyslipidemia $^{3-5}$. The role of hypothyroxinemia in cardiovascular diseases may be explained by thyroid hormone receptors present both myocardial and endothelial tissues ${ }^{6}$. On the other hand decreased thyroid hormone levels is associated with dyslipidemia that is related to coroner artery diseases. So overt hypothyroxinemia is related with cardiovascular disease.as an initiating or exacerbating factor. However, there is a limited study with inconsistent findings regarding $\mathrm{SH}$ and the presence of metabolic abnormalities ${ }^{6-8}$.

Obesity is one of the well-known risk factors related to $\mathrm{SH}$ as a cause or consequence of it. The prevalence of $\mathrm{SH}$ among obese children was estimated as $10-23 \%^{9 ; 10}$. Despite the unclarity, the potential underlying mechanism of SH in children with obesity, some possible explanation provided in the literature; an adaptation process for increasing energy expenditure, a functional disorder in the hypothalamic-pituitary-thyroid axis, resistance to thyroid hormones, increased leptin related production of thyroid releasing hormone ${ }^{2 ; 9}$.

Both obesity and hypothyroidism is related to increased cardiovascular risk. Thereby, early recognition of cardiovascular risk in patients with obesity and SH has become more critical. The aim of the study was to compare cardiovascular risk factors in obese patients with or without $\mathrm{SH}$, also to estimated the prevalence of $\mathrm{SH}$ in obese children and adolescents.

\section{MATERIAL AND METHODS}

This study was performed in the Pediatric Endocrinology Department of Cumhuriyet University Hospital. Two hundred sixty-three obese children 6-18 years of age who had been brought to the outpatient clinic were consecutively recruited for the study from September 2017 to
November 2018. The exclusion criteria were a history of chronic disorders, hypertension, use of thyroid hormone or any medications, patients with familial cardiovascular risk factors, autoimmune thyroid diseases or 1odine deficiency, secondary obesity, and TSH level higher than $10 \mathrm{IU} / \mathrm{mL}$. After exclusion of 37 patient, 219 subjects were divided into two groups according to TSH levels; Euthyroid group $(\mathrm{n}=195)$ and subclinical hypothyroid group $(\mathrm{n}=31)$. The institutional Ethics Committee approved the study protocol.

All patients weights were determined using a calibrated digital scale, and their heights were measured in triplicate to the nearest millimeter using a calibrated stadiometer. Blood pressure was measured with a sphygmomanometer cuff suitable for the subject's arm circumference while the subject was seated. Blood pressure readings were taken twice, 2 min apart, and the average measurement was recorded. Body mass index (BMI) was calculated as weight in kilograms divided by height in meters squared $\left(\mathrm{kg} / \mathrm{m}^{2}\right)$. Obesity was defined, according to the BMI percentiles for the Turkish population based on gender and age, as being $\geq 95$ th percentile ${ }^{11}$.

Venous blood samples were obtained from all of the patients from the antecubital region between 8.00 and 8.30 am after an 8-12 hour overnight fast. The serum sample tubes were allowed to clot before centrifugation. After centrifugation at $4{ }^{\circ} \mathrm{C}$ for 15 minutes at $3500 \mathrm{rpm}$, serum insulin, HDL, LDL, cholesterol, triglyceride TSH, free T4 levels were determined with the electrochemiluminescent immunoassay (Roche Cobas e601, Germany). Serum blood glucose, serum alanine aminotransferase (ALT) and aspartate aminotransferase (AST)concentrations were measured colorimetric method (Mindray BS 2000, China).

Subclinical hypothyroidism was defined as elevated serum TSH levels $(4.5-10.0 \mathrm{mIU} / \mathrm{L})$ in the presence of normal serum concentrations of free thyroxine level. We assessed insulin sensitivity using the homeostasis model of insulin resistance (HOMA-IR) index as a surrogate marker for insülin resistance. HOMA-IR values were calculated using the following formula: [fasting insulin level $(\mu \mathrm{U} / \mathrm{mL})$ multiplied by fasting glucose level $(\mathrm{mg} / \mathrm{dL})$ and divided by $405]^{12}$. The atherogenic index of plasma (AI) was calculated the logarithm of the molar ratio of triglyceride to high-density lipoprotein cholesterol (TG/HDL-C) ${ }^{13}$. 


\section{RESULTS}

Prevalence of SH was estimated as $14.1 \%$. The mean ages of euthyroid and subclinical hypothyroid groups were similar $(12.03 \pm 3.1$ and $12.09 \pm 2.5$ years, respectively, $\mathrm{p}=0.92)$. The groups were also similar according to their sex and pubertal status $(\mathrm{p}=0.33$ and $\mathrm{p}=0.99$, respectively). The values of fasting glucose, fasting insülin, ALT, AST, TSH, HOMA-IR levels were significantly higher in SH group than euthyroid group, whereas weight-SDS, height SDS, BMI-SDS, systolic and diastolic BP, triglyceride, HDL, LDL, fT4 and AI were similar $(p>0.05)$. The baseline metabolic and anthropometric characteristics of the study population have been presented in Table 1 .

Table 1: Baseline metabolic and anthropometric characteristics of the study population

\begin{tabular}{|c|c|c|c|}
\hline & $\begin{array}{c}\text { SH Group } \\
(\mathrm{n}=31)\end{array}$ & $\begin{array}{l}\text { Euthyroid Group } \\
\qquad(\mathrm{n}=195)\end{array}$ & $\mathbf{p}$ \\
\hline Age, years & $12.09 \pm 2.5$ & $12.03 \pm 3.1$ & 0.92 \\
\hline Gender (\% Girls) & 61.3 & 51.3 & 0.33 \\
\hline Weight Z-score & $2.48 \pm 1.08$ & $2.51 . \pm 1.02$ & 1.08 \\
\hline Height Z-score & $0.53 \pm 0.97$ & $0,62 \pm 1.03$ & 0.87 \\
\hline BMI Z-score & $2.35 \pm 0.76$ & $2.34 \pm 0.73$ & 0.89 \\
\hline Prepuberty (\%) & 35,5 & 36.9 & 0.99 \\
\hline $\mathrm{SBP}(\mathrm{mm}-\mathrm{Hg})$ & $119.7 \pm 17.5$ & $116.8 \pm 14.8$ & 0.39 \\
\hline DBP $(\mathrm{mm}-\mathrm{Hg})$ & $80 \pm 14.7$ & $76.3 \pm 14.2$ & 0.16 \\
\hline Fasting glucose $(\mathrm{mg} / \mathrm{dL})$ & $85.9 \pm 6.7$ & $82.8 \pm 6.0$ & 0.01 \\
\hline Fasting insulin $(\mathrm{IU} / \mathrm{mL})$ & $22.8 \pm 8.9$ & $18.2 \pm 9.6$ & 0.01 \\
\hline Triglyceride $(\mathrm{mg} / \mathrm{dL})$ & $129.5 \pm 64.1$ & $110.7 \pm 56.3$ & 0.10 \\
\hline Cholesterol (mg/dL) & $167.5 \pm 26.6$ & $158.9 \pm 31.6$ & 0.16 \\
\hline HDL $(\mathrm{mg} / \mathrm{dL})$ & $44.6 \pm 8.17$ & $44.8 \pm 9.7$ & 0.92 \\
\hline LDL $(\mathrm{mg} / \mathrm{dL})$ & $97.0 \pm 23.2$ & $92 \pm 26.9$ & 0.34 \\
\hline $\operatorname{ALT}(\mathrm{IU} / \mathrm{L})$ & $28.4 \pm 23.0$ & $21.8 \pm 14.9$ & 0.04 \\
\hline AST (IU/L) & $24.5 \pm 11.3$ & $21.3 \pm 7.3$ & 0.05 \\
\hline TSH (IU/mL) & $6.14 \pm 1.25$ & $2.63 \pm 0.89$ & 0.000 \\
\hline FT4 (ng/dL) & $1.26 \pm 0.13$ & $1.28 \pm 0.18$ & 0.63 \\
\hline HOMA-IR & $4.84 \pm 1.87$ & $3.75 \pm 2.06$ & 0.006 \\
\hline AI & $0.42 \pm 0.26$ & $0.35 \pm 0.25$ & 0.18 \\
\hline \multicolumn{4}{|c|}{$\begin{array}{l}\text { Data are given as mean } \pm \mathrm{sd}, \mathrm{SH} \text {, subclinical hypothyroid BMI, Body Mass Index; SBP, Systolic Blood } \\
\text { Pressure; DBP, Diastolic Blood Pressure; HDL, High-Density Lipoprotein; LDL Low-Density Lipoprotein; } \\
\text { ALT, Alanine aminotransferase; AST, Aspartate aminotransferase; HOMAIR, Homeostasis Model Of Insulin } \\
\text { Resistance; AI, Atherogenic Index }\end{array}$} \\
\hline
\end{tabular}

After the study group stratified into quartiles, we compared anthropometric and metabolic parameters in the first quartiles $(\mathrm{TSH}<25$. Percentile) and fourth quartiles; fasting glucose, fasting insülin, HDL, ALT, AST, HOMA-IR, and AI were different (Table 2).

When the correlation between TSH and anthropometric and metabolic parameters were evaluated, there was a positive correlation between fasting glucose, insülin, triglyceride, ALT, AST, HOMA-IR and AI (Figure 1). Even after an adjustment for BMI, the variables still remained significantly associated with the mean TSH level except for triglyceride and AI. However, there was no correlation between TSH and age weight-SDS, height SDS, BMI-SDS, systolic and diastolic BP, total cholesterol HDL and LDL ( $>0.05$ ). A multiple regression analysis was carried out with TSH as dependent variables, and BMI-SDS, total cholesterol HDL, LDL and triglyceride as independent variables. It was demonstrated that TSH levels were significantly related to HOMA-IR value $(\mathrm{p}=0.001)$ (Table 3$)$. 
Table 2: Comparison of anthropometric and metabolic parameters according to first $(\mathrm{TSH}<2.08)$ and fourth $(\mathrm{TSH}>3.65)$ quartiles

\begin{tabular}{|c|c|c|c|}
\hline & $\begin{array}{c}\text { TSH }<25 p \\
(n=56)\end{array}$ & $\begin{array}{c}\text { TSH>75p } \\
(n=56)\end{array}$ & $\mathbf{p}$ \\
\hline TSH (IU/mL) & $2.63 \pm 0.89$ & $6.14 \pm 1.25$ & 0.000 \\
\hline BMI Z-score & $2.39 \pm 0.81$ & $2.34 \pm 0.63$ & 0.74 \\
\hline Fasting glucose $(\mathrm{mg} / \mathrm{dL})$ & $81.65 \pm 7.65$ & $85.39 \pm 6.31$ & 0.006 \\
\hline Fasting insulin $(\mathrm{IU} / \mathrm{mL})$ & $17.54 \pm 9.43$ & $22.1 \pm 1.1$ & 0.01 \\
\hline Triglyceride $(\mathrm{mg} / \mathrm{dL})$ & $106 \pm 53.66$ & $122.24 \pm 55.88$ & 0.125 \\
\hline Cholesterol (mg/dL) & $167.5 \pm 26.6$ & $158.9 \pm 31.6$ & 0.16 \\
\hline $\mathrm{HDL}(\mathrm{mg} / \mathrm{dL})$ & $47.12 \pm 10.28$ & $43.03 \pm 7.39$ & 0.019 \\
\hline $\mathrm{LDL}(\mathrm{mg} / \mathrm{dL})$ & $93.35 \pm 25.27$ & $89.53 \pm 25.52$ & 0.43 \\
\hline $\operatorname{ALT}(\mathrm{IU} / \mathrm{L})$ & $18.78 \pm 8.44$ & $27.7 \pm 21.3$ & 0.005 \\
\hline AST (IU/L) & $19.6 \pm 6.84$ & $24.1 \pm 10.93$ & 0.003 \\
\hline HOMA-IR & $3.56 \pm 2.04$ & $4.69 \pm 2.8$ & 0.006 \\
\hline AI & $0.30 \pm 0.27$ & $0.41 \pm 0.23$ & 0.025 \\
\hline
\end{tabular}

Data are given as mean \pm sd, TSH, thyroid stimulating hormone; BMI, Body Mass Index; HDL, High-Density Lipoprotein; LDL Low-Density Lipoprotein; ALT, Alanine aminotransferase; AST, Aspartate aminotransferase; HOMAIR, Homeostasis Model Of Insulin Resistance; AI,
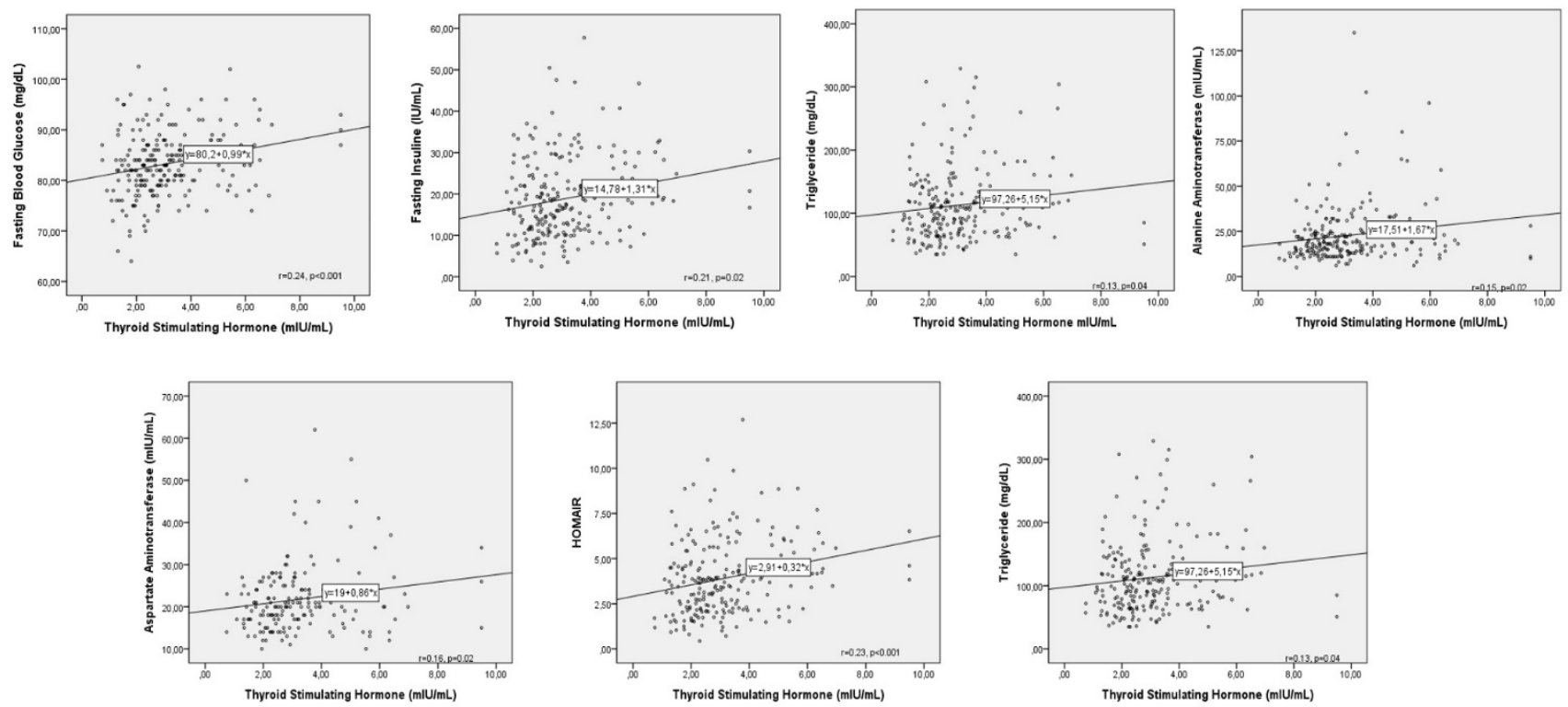

Figure 1: Correlations between TSH and several anthropometric and metabolic parameters 
Table 3: Multiple regression analysis between TSH level with anthropometric and metabolic parameters

\begin{tabular}{|c|c|c|}
\hline Variable & B-Coefficient (95\% CI) & p \\
\hline BMI-SDS & $-0.76(-0.46-0.13)$ & 0.28 \\
\hline TRIGLICERIDE & $-0.23(-0.03-0.02)$ & 0.64 \\
\hline CHOLESTEROL & $0.81(-0.09-0.17)$ & 0.55 \\
\hline HDL & $-0.24(-0.17-0.09)$ & 0.56 \\
\hline LDL & $-0.69(-0.17-0.09)$ & 0.55 \\
\hline HOMA-IR & $0.25(0.08-0.29)$ & 0.001 \\
\hline
\end{tabular}

\section{DISCUSSION}

We found that TSH level was independently associated with HOMA-IR levels as a surrogate marker of insülin resistance in obese children and adolescents. Additionally, obese subjects with SH had higher serum transaminase levels when compared without SH. This data suggested that obese patients with SH may be more susceptible to metabolic complications than euthyroid subjects.

It has been shown that not only overt hypothyroidism but also SH is closely associated with insulin resistance that is one of the most important factors playing roles in the origin of the cardiovascular alterations and type 2 diabetes ${ }^{14}$. The genes that regulate glucose homeostasis at the liver and peripheral tissues are directly influenced by thyroid hormones ${ }^{15}$. We found that TSH level was independently associated with HOMA-IR levels. In a retrospective study that the patients were subdivided into two groups according to TSH level based on $2.5 \mu \mathrm{IU} / \mathrm{mL}$, Individuals with TSH Levels $>2.5$ had higher HOMA-IR and lower HDL levels ${ }^{16}$. Similarly, Nader at al ${ }^{17}$. suggested that increased TSH level is associated with higher triglyceride levels and elevated HOMA-IR values. On the contrary, Cerbone at al ${ }^{18}$. showed that HOMA-IR value was not different in subjects with SH versus controls.

The relationship with hepatic steatosis and subclinical hypothyroidism has been recently shown in children ${ }^{19 ; 20}$. In a retrospective study of 332 overweight or obese children and adolescents, Kaltenbach et al. ${ }^{19}$ showed that higher TSH levels are associated with a greater degree of fatty infiltration on ultrasound imaging. Hypertransaminasemia, if other reasons exclude, is one of the important markers for hepatic steatosis in obese children and adolescents. In our study, slightly but significantly elevated hypretransaminasemia may be related to subtle hepatic steatosis. We also found that ALT and AST levels in obese subjects with $\mathrm{SH}$ were positively correlated with TSH levels. It has also been shown that $\mathrm{SH}$ associated with hepatic steatosis independently of metabolic risk factors. It is uncertain, how hypertrotropinemia exactly affects serum transaminase levels. It may be explained that thyroid hormones and hepatic steatosis share common genetic and environmental influences ${ }^{21}$.

A positive association of TSH and anthropometric parameters in obese children and adolescents were reported in the literature ${ }^{1 ; 2 ; 8 ; 9 ; 19 ; 22 ; 23}$. Dahl et al. ${ }^{22}$ showed that TSH concentrations were associated positively with waist-height ratio. However, we did not show a correlation with the severity of obesity (BMI-SDS) and TSH levels. Similarly, Kumar et al. failed to show any correlation between TSH and BMI-SDS. This discrepancy may be explained by small sample size. On the other hand, we use the BMI-SDS as a marker for the severity of obesity. However, there are limitations in use of BMI as a measure of adiposity for the pediatric population, due to variation in BMI with age, sex, puberty, and race or ethnicity ${ }^{24,25}$. Moreover, it was reported that BMI had a low sensitivity to determine the degree of adiposity ${ }^{26}$.

The prevalence of SH is $4-20 \%$ in adults, and 1.5 $3 \%$ in children ${ }^{2}$. On the other hand, obese children and adolescent have higher prevalence of SH than lean peers. In line with literature, the present study showed that prevalence of $\mathrm{SH}$ in obese children and adolescent is $14.1 \%$. Elevated TSH levels seem to be a consequence instead of cause. Zhang et $\mathrm{al}^{23}$ showed that TSH level was positively correlated with waist circumference. 
Moreover, several studies demonstrated that the TSH level tends to decrease with weight loss ${ }^{27,28}$.

Our study has several limitations. First, the small sample size of the cohort might have failed to satisfy to conclude the subclinical hypothyroidism and its effects on metabolic parameters. Second, our study design was retrospective and crosssectional, which may not provide definitive information about cause-and-effect relationships.

In conclusion, obese children and adolescents with SH have increased subclinical alterations of cardiovascular risk factors and higher risk for hepatic steatosis when compared without SH. Larger comprehensive prospective studies with an increased number of cases in each group are needed to explore the relationship between $\mathrm{SH}$ and metabolic alterations in obese children and adolescents with SH.

\section{REFERENCES}

1. Biondi B, Cooper DS: The clinical significance of subclinical thyroid dysfunction. Endocr Rev 2008;29:76-131.

2. Salerno M, Capalbo D, Cerbone M, De LF: Subclinical hypothyroidism in childhood - current knowledge and open issues. Nat Rev Endocrinol 2016;12:734746.

3. Hak AE, Pols HA, Visser TJ, Drexhage HA, Hofman A, Witteman JC: Subclinical hypothyroidism is an independent risk factor for atherosclerosis and myocardial infarction in elderly women: the Rotterdam Study. Ann Intern Med 2000;132:270-278.

4. Diekman T, Lansberg PJ, Kastelein JJ, Wiersinga WM: Prevalence and correction of hypothyroidism in a large cohort of patients referred for dyslipidemia. Arch Intern Med 1995;155:1490-1495.

5. Staub JJ, Althaus BU, Engler H, Ryff AS, Trabucco P, Marquardt K, Burckhardt D, Girard J, Weintraub BD: Spectrum of subclinical and overt hypothyroidism: effect on thyrotropin, prolactin, and thyroid reserve, and metabolic impact on peripheral target tissues. Am J Med 1992;92:631-642.

6. Jabbar A, Pingitore A, Pearce SH, Zaman A, Iervasi G, Razvi S: Thyroid hormones and cardiovascular disease. Nat Rev Cardiol 2017;14:39-55.

7. Bossowski A, Sawicka B, Szalecki M, Koput A, Wysocka J, ZelazowskaRutkowska B: Analysis of serum adiponectin, resistin and leptin levels in children and adolescents with autoimmune thyroid disorders. J Pediatr Endocrinol Metab 2010;23:369-377.

8. Marwaha RK, Tandon N, Garg MK, Kanwar R, Sastry A, Narang A, Arora S, Bhadra K: Dyslipidemia in subclinical hypothyroidism in an Indian population. Clin Biochem 2011;44:1214-1217.

9. Reinehr $\mathrm{T}$ : Thyroid function in the nutritionally obese child and adolescent. Curr Opin Pediatr 2011;23:415-420.

10. Vigone MC, Capalbo D, Weber G, Salerno M: Mild Hypothyroidism in Childhood: Who, When, and How Should Be Treated? J Endocr Soc 2018;2:10241039.

11. Bundak R, Furman A, Gunoz H, Darendeliler F, Bas F, Neyzi O: Body mass index references for Turkish children. Acta Paediatr 2006;95:194-198.

12. Conwell LS, Trost SG, Brown WJ, Batch JA: Indexes of insulin resistance and secretion in obese children and adolescents: a validation study. Diabetes Care 2004;27:314-319.

13. Shen S, Lu Y, Qi H, Li F, Shen Z, Wu L, Yang C, Wang L, Shui K, Wang Y, Qiang $\mathrm{D}$, Yun J, Weng X: Association between ideal cardiovascular health and the atherogenic index of plasma. Medicine (Baltimore) 2016;95:e3866.

14. Ormazabal V, Nair S, Elfeky O, Aguayo C, Salomon C, Zuniga FA: Association between insulin resistance and the development of cardiovascular disease. Cardiovasc Diabetol 2018;17:122.

15. Brenta G: Why can insulin resistance be a natural consequence of thyroid dysfunction? J Thyroid Res 2011;2011:152850.

16. Souza LL, Guedes EP, Teixeira PF, Moreira RO, Godoy-Matos AF, Vaisman M: Serum TSH levels are associated with cardiovascular risk factors in overweight and obese adolescents. J Pediatr (Rio J ) 2016;92:532-538.

17. Nader NS, Bahn RS, Johnson MD, Weaver AL, Singh R, Kumar S: Relationships between thyroid function and lipid status or insulin resistance in a pediatric population. Thyroid 2010;20:1333-1339.

18. Cerbone M, Capalbo D, Wasniewska M, Mattace RG, Alfano S, Meli R, De LF, Salerno M: Cardiovascular risk factors in children with long-standing untreated 
idiopathic subclinical hypothyroidism. J Clin Endocrinol Metab 2014;99:26972703.

19. Kaltenbach TE, Graeter T, Oeztuerk S, Holzner D, Kratzer W, Wabitsch M, Denzer C: Thyroid dysfunction and hepatic steatosis in overweight children and adolescents. Pediatr Obes 2017;12:67-74.

20. Pacifico L, Bonci E, Ferraro F, Andreoli G, Bascetta S, Chiesa C: Hepatic steatosis and thyroid function tests in overweight and obese children. Int $J$ Endocrinol 2013;2013:381014.

21. Walsh JP: Setpoints and susceptibility: do small differences in thyroid function really matter? Clin Endocrinol (Oxf) 2011;75:158-159.

22. Dahl M, Ohrt JD, Fonvig CE, Kloppenborg JT, Pedersen O, Hansen T, Holm JC: Subclinical Hypothyroidism in Danish Lean and Obese Children and Adolescents. J Clin Res Pediatr Endocrinol 2017;9:8-16.

23. Zhang J, Jiang R, Li L, Li P, Li X, Wang $\mathrm{Z}$, Li L, Teng W: Serum thyrotropin is positively correlated with the metabolic syndrome components of obesity and dyslipidemia in chinese adolescents. Int $\mathbf{J}$ Endocrinol 2014;2014:289503.

24. Neovius MG, Linne YM, Barkeling BS, Rossner SO: Sensitivity and specificity of classification systems for fatness in adolescents. Am J Clin Nutr 2004;80:597603.

25. Han JC, Lawlor DA, Kimm SY: Childhood obesity. Lancet 2010;375:1737-1748.

26. Neovius M, Rossner SM, Vagstrand K, von Hausswolff-Juhlin YL, Hoffstedt J, Ekelund U: Adiposity measures as indicators of metabolic risk factors in adolescents. Obes Facts 2009;2:294-301.

27. Reinehr T, Isa A, de SG, Dieffenbach R, Andler W: Thyroid hormones and their relation to weight status. Horm Res 2008;70:51-57.

28. Wolters B, Lass N, Reinehr T: TSH and free triiodothyronine concentrations are associated with weight loss in a lifestyle intervention and weight regain afterwards in obese children. Eur $\mathrm{J}$ Endocrinol 2013;168:323-329. 